\title{
Economic analysis of the sustainability of Volgograd region in various scenarios of pension age in the Russian Federation
}

\author{
Oleg Likhomanov \\ Volgograd State University, \\ Institute of Management and Regional Economics \\ Chair of Applied Informatics and Mathematical Methods in \\ Economics \\ Volgograd, Russia \\ likhomanov.oleg@volsu.ru
}

\author{
Marina Lapina \\ Volgograd State University, \\ Institute of Management and Regional Economics \\ Chair of Applied Informatics and Mathematical Methods in \\ Economics \\ Volgograd, Russia \\ lapina.m.s@volsu.ru
}

\author{
Polina Tovpeko \\ Volgograd State University, \\ Institute of Economics and Finance \\ Chair of Theory of Finance, Credit and Taxation \\ Volgograd, Russia \\ tovpekopolina@volsu.com
}

\begin{abstract}
The global trend that has engulfed the world is the aging of the population. This is the reason for the urgency of the discussion on reforming traditional social security systems. The purpose of this study is to analyze the optimality of the population structure by the example of the Volgograd region, using various scenarios for raising the retirement age. The scientific novelty of the study is that it has developed a holistic approach to studying the problem of changing (increasing) the retirement age in the context of demographic processes, the situation in the labor market and in the pension sector. The article compares the age of retirement and the average life expectancy after retirement for the Russian Federation, Moscow, the Volgograd region, and some selected countries for analysis. According to the results of the study, the size of the minimum and average pensions in the countries selected for analysis is presented and the average life expectancy after retirement for men and women is predicted in 2021, based on various retirement-age scenarios. Using the age-shifting method, the prognosis of the number of the able-bodied population of the Volgograd Region in 2021 is provided. The results of calculations of the pension, potential and general workload indicators for men and women in the Volgograd Region in 2016 and 2021 are given. for different scenarios of retirement age. In the course of this study, an analysis was made of the optimality of the age composition of the population, in the forecast period by the Rosstat method. Based on the analysis of the situation with the able-bodied population in the Volgograd region, a conclusion was made about the inevitability of raising the retirement age in the Russian Federation.
\end{abstract}

Keywords- labor resources, demography, forecasting, ageshifting method, pension system, labor load indicators, age structure of the population

\section{INTRODUCTION}

In a message to the Federal Assembly on December 1, 2016, Russian President Vladimir Putin stated: "The meaning of our entire policy is the saving of people, the multiplication of human capital as the main wealth of Russia. Therefore, our efforts are aimed at supporting traditional values and families, demographic programs, improving ecology, human health, and developing education and culture, "the head of state said.

Consequently, all economic and social development strategies of the Russian Federation must be subordinated to this meaning. But who will implement various ambitious projects and plans, whether there is enough quantitative and qualitative labor resources for their implementation, or it is necessary to adjust development strategies to the capabilities of human resources, that is, as the main restriction in the developed socio-economic development models to accept the availability of human capital. The article makes an attempt to predict the quantitative composition of labor resources in the Volgograd region, taking into account possible scenarios for raising the retirement age in the Russian Federation.

The demographic situation in the Russian Federation raises serious concerns not only among specialists, it manifests itself in the social and economic relations of the population, is closely related to the labor market, external and internal labor migration. The government's calculations predicting an 
increase in the retirement age, as well as the financial provision of pensioners, causes alarming expectations among the population, pushes for "gray" wage schemes. Volgograd Region, which is among the dying regions by the rating of resilience of Rosstat, is typical for the European part of Russia.

For the purpose of measuring population aging, the indicator of demographic aging is used. This indicator characterizes the proportion of the population aged 60 years and over (according to UN criteria - 65 years and older) in the entire population.

In Russia, to measure the level of old age population, the scales of demographic aging are used, where the age of 60 years and older is taken as a criterion. To do this, use the scale of J. Bože-Garnier-E. Rosset.

TABLE I.

\section{SCALE OF G.BOGO-GARNIER-E.ROSET}

\begin{tabular}{|c|c|}
\hline $\begin{array}{c}\text { Specific weight of persons aged 60 years } \\
\text { and older, } \%\end{array}$ & Old age of the population \\
\hline less than 8 & Demographic youth \\
\hline $8-10$ & The first threshold of old age \\
\hline $10-12$ & $\begin{array}{c}\text { Actually the threshold of old } \\
\text { age }\end{array}$ \\
\hline 12 u выme & Demographic aging \\
\hline $12-14$ & $\begin{array}{c}\text { Initial level of demographic } \\
\text { aging }\end{array}$ \\
\hline $14-16$ & $\begin{array}{c}\text { The average level of } \\
\text { demographic aging }\end{array}$ \\
\hline $16-18$ & $\begin{array}{c}\text { High level of demographic } \\
\text { aging }\end{array}$ \\
\hline 18 и выme & $\begin{array}{c}\text { Very high level of demographic } \\
\text { old age }\end{array}$ \\
\hline
\end{tabular}

Note: compiled according to [1].

For countries where the age of 65 years and older is taken as a criterion, the United Nations demographic aging scale can be used.

TABLE II. THE UNDOGRAPHICAL AGING SCALE

\begin{tabular}{|c|c|}
\hline $\begin{array}{c}\text { Specific weight of persons aged 65 years } \\
\text { and older, } \%\end{array}$ & Old age of the population \\
\hline less than 4 & Young people \\
\hline $4-7$ & $\begin{array}{c}\text { Population at the threshold of } \\
\text { old age }\end{array}$ \\
\hline более 7 & Old population \\
\hline
\end{tabular}

Note: compiled according to [1].

The authors made an attempt to make a short-term fiveyear forecast of the situation with human resources under different scenarios of legislative definition of retirement age.
TABLE III. AGE OF PENSION EXPENDITURE AND AVERAGE LIFETIME IN SOME COUNTRIES

\begin{tabular}{|c|c|c|c|c|c|c|c|}
\hline \multirow{2}{*}{\multicolumn{2}{|c|}{ A country }} & \multicolumn{2}{|c|}{$\begin{array}{c}\text { Age of } \\
\text { retirement, } \\
\text { years }\end{array}$} & \multicolumn{2}{|c|}{$\begin{array}{c}\text { Average life } \\
\text { expectancy, } \\
\text { years }\end{array}$} & \multicolumn{2}{|c|}{$\begin{array}{c}\text { Average life } \\
\text { expectancy } \\
\text { after } \\
\text { retirement, } \\
\text { years }\end{array}$} \\
\hline & & $\begin{array}{l}\text { Men' } \\
s\end{array}$ & $\begin{array}{c}\text { Wome } \\
n\end{array}$ & $\begin{array}{c}\text { Men' }^{\prime} \\
s\end{array}$ & $\begin{array}{c}\text { Wome } \\
n\end{array}$ & $\begin{array}{c}M^{\prime}{ }^{\prime} \\
s\end{array}$ & $\begin{array}{c}\text { Wome } \\
n\end{array}$ \\
\hline \multirow{3}{*}{$\begin{array}{c}\text { Russ } \\
\text { ia }\end{array}$} & $\begin{array}{l}\text { Average in } \\
\text { the Russian } \\
\text { Federation }\end{array}$ & \multirow[t]{3}{*}{60} & \multirow[t]{3}{*}{55} & 66,5 & 77,1 & 6,5 & 22,1 \\
\hline & Moscow & & & 73,5 & 80,4 & 13,5 & 25,4 \\
\hline & Volgograd & & & 67,3 & 77,5 & 7,3 & 22,5 \\
\hline \multicolumn{2}{|r|}{ Ukraine } & 60 & $\begin{array}{c}55 \rightarrow 6 \\
0\end{array}$ & 62,2 & 74,0 & 2,2 & 19,0 \\
\hline \multicolumn{2}{|c|}{ Germany } & 67 & 65 & 76,0 & 82,1 & 9 & 17,1 \\
\hline \multicolumn{2}{|c|}{ France } & 62,5 & 62,5 & 77,7 & 84,3 & 15,2 & 21,8 \\
\hline \multicolumn{2}{|c|}{ United Kingdom } & 65 & 60 & 76,1 & 81,3 & 11,1 & 21,3 \\
\hline \multicolumn{2}{|c|}{ USA } & 65 & 65 & 75,2 & 81,0 & 10,2 & 16 \\
\hline \multicolumn{2}{|r|}{ Italy } & 66 & 66 & 77,0 & 83,1 & 11 & 17,1 \\
\hline \multicolumn{2}{|r|}{ China } & 60 & 55 & 71,1 & 74,8 & 11,1 & 19,8 \\
\hline
\end{tabular}

Table 3 requires some clarification.

Pensioners in Germany are a quarter of the population. The minimum pension is $€ 350$, it is put to all residents, even emigrants, all pensioners are guaranteed payment, at the expense of municipalities, communal services on an area of 56 sq.m. When retiring before the term, $0.3 \%$ of the pension for each unfinished month is deducted. At the German level of costs, retirees lead a very modest lifestyle [2].

In France, they retire at the age of 60. The minimum pension is $€ 500$ per month. The pension is calculated in the amount of 50 per cent of the wages of the last 11 working years. If the length of service is $41 \mathrm{~g}$, a full pension is calculated. For each missing quarter of work experience, the size of the pension is reduced by $1.25 \%$ [2].

In the UK there is a state, basic and professional pension. A state pension has the right to receive any citizen of the kingdom who has reached the retirement age. In 2016, UK retirees receive a state pension, the size of which is the same for all, at a rate of $£ 605$ per month. To help the elderly, discounts, benefits and free services are provided. The state helps to pay for housing, medicines and transportation. The basic pension in the UK depends on the length of service and the amount of wages. Payments in the amount of $20 \%$ of the average salary of the employee are guaranteed. The laws of Great Britain in this area often change [2].

In the US, the minimum pension is $\$ 300$. Pensions are assigned to everyone who does not even have a working experience. It is allowed to retire earlier than the due date, but then the size of pensions is reduced by $20 \%$. It is allowed to open a personal pension account, limited to \$2000 a year. [2].

In Italy, the pension system is so complex that its description will require many explanations. In 2012, in Italy, pension reform was carried out, as a result of which the age of retirement for men and women was increased and equalized to 66 years. There was a possibility of early retirement with a working experience of 41 years and 6 months for women and 42 years and 6 months for men [2]. 
In China, the pension system is in the process of reform. The state pension is received only by civil servants who have worked for at least 15 years, although recently the pension is also provided for workers. Pensioners who have worked in the countryside have relatives [2].

In 2016, according to the Ministry of Health, the average life expectancy in Russia was $72.1 \mathrm{~g}$. According to the provision contained in the approved plan for the implementation of the third stage of the Concept of Demographic Policy, published on the website of the Cabinet of Ministers, by 2020 the number of citizens of the Russian Federation can reach 147.5 million people, and the life expectancy of Russians will grow to 74 years. The plan also implies that by 2020 the projected number should be provided with a migration increase of at least 200 thousand people in the city [3].

If we assume that the ratio of men and women in calculating the average life expectancy will remain the same, you can calculate the average life expectancy of the population after retirement under different scenarios for the retirement age.

TABLE IV. AVERAGE PENSIONS ON CERTAIN COUNTRIES

\begin{tabular}{|c|c|}
\hline \multirow{2}{*}{ A country } & Average pension for some countries \\
& \\
\hline & \\
\hline Russia & $\begin{array}{c}\text { Average in the Russian Federation } 12406 \text { rub. } \\
\text { In Moscow, 15,200 rubles. } \\
\text { In Volgograd, } 11840 \text { rubles. }\end{array}$ \\
\hline Ukraine & 1100 UAH. (2946.5 rub.) \\
\hline Germany & $€ 1290(93000$ rub.) \\
\hline France & $£ 1000(64800$ rub.) \\
\hline United Kingdom & $\$ 1200(68000$ rub.) \\
\hline USA & $¥ 1000(64000$ rub.) \\
\hline Italy & $¥ 1000$ (9600 rub.) \\
\hline China & \\
\hline Note: compiled according to [1].
\end{tabular}

If we try to analyze average pensions in Russia and in economically developed countries, then we should not forget that exchange rates are indicated. Exchange rates for their purchasing power sharply differ from stock exchange ones: by $30-50 \%$ [4]. The peculiarities of the consumption pattern in Russia and selected countries do not allow making unambiguous conclusions on the size of the accrued pensions, although the fact of the meagerness of pension accruals in Russia is obvious.

Important for analysis is the time of actual survival. It is calculated by subtracting the retirement age from the average life expectancy.
TABLE V. AVERAGE LIFE EXPECTANCY AFTER RETIREMENT

\begin{tabular}{|c|c|c|c|c|c|c|}
\hline \multirow[t]{2}{*}{$\begin{array}{c}\text { A } \\
\text { country }\end{array}$} & \multicolumn{2}{|c|}{$\begin{array}{c}\text { Age of } \\
\text { retirement, } \\
\text { years }\end{array}$} & \multicolumn{2}{|c|}{$\begin{array}{c}\text { Average life } \\
\text { expectancy, years }\end{array}$} & \multicolumn{2}{|c|}{$\begin{array}{c}\text { Average life } \\
\text { expectancy after } \\
\text { retirement, years }\end{array}$} \\
\hline & Men's & Women & Men's & Women & Men's & Women \\
\hline \multirow{3}{*}{ Russia } & 60 & 55 & \multirow{3}{*}{67,9} & \multirow{3}{*}{78,7} & 7,9 & 23,7 \\
\hline & 65 & 60 & & & 2,9 & 18,7 \\
\hline & 65 & 63 & & & 2,9 & 15,7 \\
\hline
\end{tabular}

Note: compiled according to [1].

\section{MATERIALS AND METHODS (MODEL)}

In connection with proposals of members of the economic block of the Government of the Russian Federation on changing the age of retirement, the authors made an attempt to forecast the number of the able-bodied population of the Volgograd region using the age-shifting method.

The method of moving ages is that data on the size and structure of the population at the beginning of the period "move" into the future, at the same time replenishing at the expense of the born and decreasing at the expense of the deceased. For this, the population of each sex-age group is multiplied by the corresponding survival ratio. As a result, we get a possible population. For the forecast of the prospective population size, the initial data are the number and age structure of the population, the number of surviving to a given age, the age-specific fertility rates for women aged 15-49, the age-specific mortality rates, and the hypotheses of trends in population reproduction and mortality in the forecast period [5].

Consider the application of the age-shifting method using the example of the forecast of the number and sex and age structure of the able-bodied population of the Volgograd region for 5 years in advance from 2016 to 2021.

We shall confine ourselves to a variant of the forecast under the hypothesis of an invariable regime for the reproduction of the population. The age-specific fertility rates for women aged 15-49 years are accepted for 2014. That is, we want to see how the population will change if the current level of fertility does not change (this assumption is unlikely). Concerning the death rate in this model, the hypothesis of its invariance during the forecast period is also accepted.

To use the method of moving age, you need to know the average number of people living in this or that age range. It should be noted that the movement should be carried out on the basis of time intervals equal to the age group of the population in such a way that with each step of the forecast the number of the surviving age group passed into the next age interval [6]. In the calculation of the five-year forecast, the hypothesis of the unchanged regime of reproduction and mortality of the population was adopted [4].

When developing measures for the appropriate use and social security of labor resources, it is necessary to determine the economic burden on persons of working age. The indicators of labor load characterize the burden on people of working age by the population of unproductive age and are calculated as follows [7]: 
1. The coefficient of potential load - the ratio of the number of people aged 0 to 15 years and the number of people of working age.

2. The coefficient of pension load - the ratio of the number of persons of retirement age and the number of people of working age.

3. Total load factor - the ratio of the number of persons of retirement age and persons aged 0 to 15 years to the number of people of working age.

The final ratio shows the number of persons of incapable working age per 1000 people of working age [2].

\section{RESULTS AND DISCUSSION}

The results of the calculation by the age-shifting method are presented in the form of a sex-age pyramid (Fig. 1 and Fig. 2.

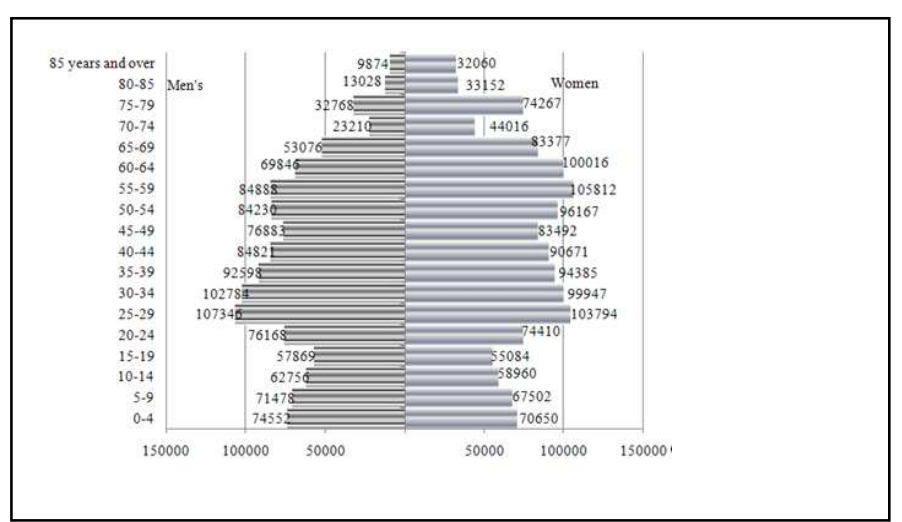

Fig. 1. The age and sex pyramid of the population of the Volgograd Region in 2016.

Note: compiled according to [1]

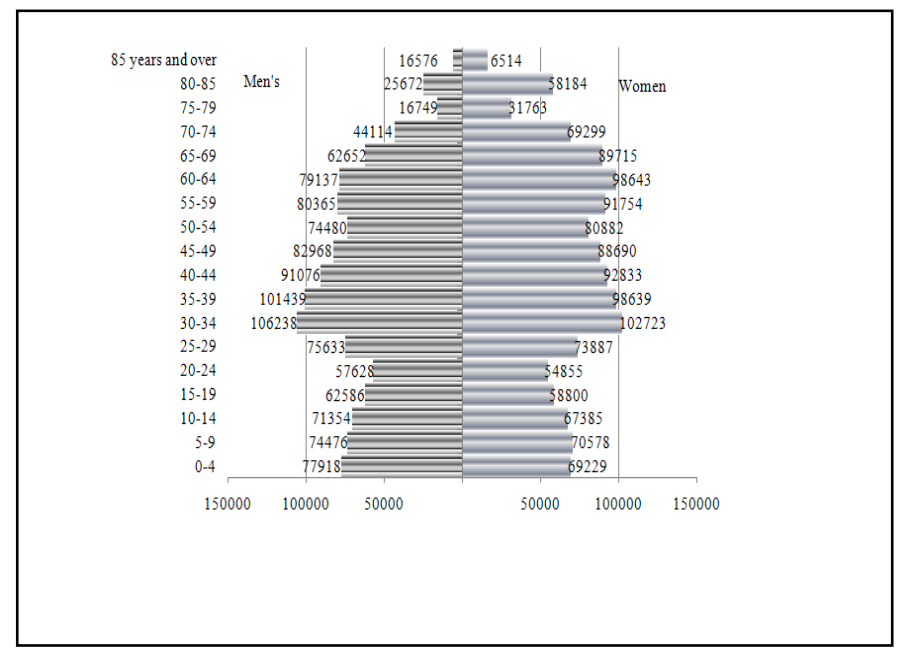

Fig. 2. Sex and age pyramid of the population of the Volgograd region in 2021.

Note: compiled according to [1]
Based on the results of the construction of the sex and age pyramid of the population of the Volgograd Region in 2016 and 2021, pyramids of regressive (depopulation) type were obtained. This type of pyramid is characterized by low fertility and high mortality.

Based on the results of calculations of labor load indicators in 2016, the total workload for the Volgograd region was 737 per 1000 people of working age (TABLE VI). Also characteristic is the excess of the pension load factor over the coefficient of potential load, which indicates that the society is working to keep the population more after the working age. The reason for this phenomenon lies in the aging of the population due to changes in the natural reproduction of the population. In 2016, as can be seen from Table 1, the coefficient of pension load for women is almost three times higher than for men.

In 2021, the total load factor, according to the forecast, will increase by $10 \%$, due to the growth of the potential load factor by $12 \%$ and the pension load factor by $8 \%$. Just as in 2016, the pension burden ratio for women is much higher than for men.

TABLE VI. INDICATORS OF LABOR LOAD FOR THE VOLGOGRAD REGION IN 2016 AND 2021 YEARS. (FOR 1000 PEOPLE WHO ARE WORSE INCONVENSIBLE)

\begin{tabular}{|c|c|c|c|}
\hline Name of the coefficient & All population & Men's & Women \\
\hline \multicolumn{2}{|c|}{2016} & 282 & 272 \\
\hline $\begin{array}{c}\text { K - coefficient of potential load } \\
\text { retirement benefit ratio } \\
\text { total load factor }\end{array}$ & 277 & 677 & 263 \\
\hline K- retirement benefit ratio & 460 & 960 & 535 \\
\hline K-total load factor & 737 & 318 & 305 \\
\hline $\begin{array}{c}\text { K - coefficient of potential load } \\
\text { retirement benefit ratio } \\
\text { total load factor }\end{array}$ & 311 & 700 & 321 \\
\hline K- retirement benefit ratio & 499 & 1018 & 626 \\
\hline \multicolumn{2}{|c|}{ K- total load factor } & 811 & \\
\hline
\end{tabular}

Note: compiled according to [1]

Today, the issue of raising the retirement age is getting more acute. Various options for increasing the retirement age are considered: 65 for men and 60 for women, 65 for men and 63 for women, and so on. In this connection, the load factors for these options were calculated. Thus, according to Table 7, with an increase in the retirement age for men under 65 and for women under 60 , the total workload ratio will decrease by $24.5 \%$, and with the variant 65 for men and 63 for women, this indicator will decrease by $35.6 \%$. It should be noted that with the latter option, the pension load ratio will decrease to almost the level of the potential load factor. 
In demography, a provision was made on the optimal age structure of the population, which provides the necessary share of the population of working age and constant reproduction of the population. The optimal composition of the population is considered when fulfilling the following ratio: the share of children is at least $20 \%$, the proportion of the able-bodied population is at least $65 \%$, the share of the elderly is no more than $15 \%[6]$.

TABLE VII. INDICATORS OF LABOR LOAD FOR THE VOLGOGRAD REGION IN 2021 YEARS. UNDER THE CONDITIONS OF INCREASING THE PENSION FAMILY (THOUSANDS OF EMPLOYED PEOPLE ARE INCONVENSIBLE)

\begin{tabular}{|c|c|c|c|}
\hline Name of the coefficient & All population & Men's & Women \\
\hline \multicolumn{4}{|c|}{65 for men and 60 for women } \\
\hline $\begin{array}{l}\mathrm{K} \text { - coefficient of potential load } \\
\text { retirement benefit ratio } \\
\text { total load factor }\end{array}$ & 277 & 279 & 276 \\
\hline $\mathrm{K}$ - retirement benefit ratio & 334 & 490 & 192 \\
\hline $\mathrm{K}-$ total load factor & 612 & 769 & 468 \\
\hline \multicolumn{4}{|c|}{65 for men and 63 for women } \\
\hline $\begin{array}{l}\mathrm{K} \text { - coefficient of potential load } \\
\text { retirement benefit ratio } \\
\text { total load factor } \\
\end{array}$ & 267 & 258 & 276 \\
\hline $\mathrm{K}$ - retirement benefit ratio & 285 & 380 & 192 \\
\hline $\mathrm{K}$ - total load factor & 522 & 638 & 468 \\
\hline
\end{tabular}

Note: compiled according to [1]

\section{CONCLUSION}

In the course of the study of the optimal age structure, the age structure of the population of the Volgograd Region in 2016 and 2021 was calculated. So, in 2016, none of the three indicators does not reach the required value (TABLE VI), therefore, the age structure of the population is not optimal. In 2021 , in addition to not optimality of the age composition of the population, its deterioration is observed. However, subject to an increase in the retirement age, in 2021 there is a decrease in the proportion of older people and an increase in the proportion of the able-bodied population, which is a positive development.

From the results of these calculations it follows that, despite the positive effect of increasing the retirement age, the optimality of the age structure of the population of the Volgograd region is not achieved, due to the insufficient proportion of children in the population.

Thus, due to the aging of the population, as well as fluctuations in its age composition by 2021 , the total burden on the able-bodied population will increase both among men and women. This is due to the growing burden of children and persons of retirement age. At the same time, the workload for the able-bodied population will increase with children. The number of persons working age, in turn, will decrease. With an increase in the retirement age, the burden on the workingage population will decrease, and the burden of the persons of the retirement age will decrease to the level of the indicator of the load of the children. However, when taking such a measure, the optimality of the age structure of the population of the Volgograd region is still not achieved.

TABLE VIII. AGE STRUCTURE OF THE POPULATION OF THE VOLGOGRAD REGION IN 2016 AND 2021. UNDER CONDITIONS OF PRESERVATION AND IMPROVEMENT OF PENSION AGE (\%)

\begin{tabular}{|c|c|c|}
\hline & All population & Specific gravity \\
\hline \multicolumn{3}{|c|}{2016} \\
\hline Total, including: & 2545937 & 100 \\
\hline younger than able-bodied & 405898 & 15,94 \\
\hline able-bodied & 1465537 & 57,56 \\
\hline over working age & 674502 & 26,49 \\
\hline \multicolumn{3}{|c|}{2021 , at preservation of a pension age } \\
\hline Total, including: & 2505434 & 100 \\
\hline younger than able-bodied & 430940 & 17,20 \\
\hline able-bodied & 1383722 & 55,23 \\
\hline over working age & 690773 & 27,57 \\
\hline \multicolumn{3}{|c|}{2021, with an increase in the retirement age $65(60)$} \\
\hline Total, including: & 2505434 & 100 \\
\hline younger than able-bodied & 430940 & 17,20 \\
\hline able-bodied & 1554613 & 62,05 \\
\hline over working age & 519882 & 20,75 \\
\hline \multicolumn{3}{|c|}{2021, with an increase in the retirement age 65 (63) } \\
\hline Total, including: & 2505434 & 100 \\
\hline younger than able-bodied & 430940 & 17,20 \\
\hline able-bodied & 1614623 & 64,44 \\
\hline over working age & 460696 & 18,39 \\
\hline
\end{tabular}

Note: compiled according to [6]

The increase in the retirement age in the Russian Federation is inevitable. This is indicated by the sex-age pyramid of the depopulation type in 2021 and the coefficients of the total workload: 1018 (there are as many as 1000 ablebodied people per 1000 able-bodied people) in women and 626 in men. To ensure the stable functioning of the economy without raising the retirement age, only a significant increase in labor productivity and the transition to a new technological structure (which is unlikely) or an increase in the flow of external labor migration will be able to (which can negatively affect the long-term period).

The increase in the retirement age must be accompanied by a number of steps of social support for the population. Otherwise, with a mechanical increase in the retirement age, the life expectancy will significantly decrease (the average life expectancy can not increase without valid reasons), pensioners will not be able to use their accumulated funds, and the whole event to increase the retirement age will turn into a highly profitable business project. 
It is necessary to accelerate the development of medicine (rather than pseudo-optimize it), improve working conditions in production and environmental conditions (especially in large populated areas), increase social protection of the population.

One should also take into account the implicit consequences of increasing the retirement age, especially among women. In European countries, the practice of attracting nannies and governesses to children is widespread. In Russia, these functions, and much more successfully, are performed by grandmothers. An increase in the retirement age for women will put them in a desperate situation. After the child reaches the age of 1.5 , the payment of the allowance is terminated, the kindergartens are accepted when the child is 3 years old. It is necessary to revise the financial component for organizing group work with children up to the age of three.

As people age, new diseases inevitably appear, additional unaccounted medical services will be required, sickness passes will increase, quality of work will worsen. We can not ignore the alarming state of expectation that affects the quality of life, especially in people of pre-retirement age, so we need a certainty and an early economically and socially justified decision to determine the age of retirement.

\section{References}

[1] Population of the Russian Federation by sex and age: Stat. Bulletin [Статистический бюллетень «Численность населения Российской Федерации по полу и возрасту: Стат. бюллетень] Statistical bulletin Available ar:: http://www.gks.ru/free_doc/doc_2016/ bul_dr / chislpv16.rar.

[2] Smirnov S.N. Regional aspects of social policy. [Региональные аспекты социальной политики]. - Moscow: Helios ARV, 1999. - 320 p.

[3] Egorova E. A Economic demography [Экономическая демография]. Moscow: Moscow International Institute of Econometrics, Informatics, Finance and Law, 2003. pp. 74-77.
[4] Runova T.G Demography: a study guide [Демография: учебное пособие]. Moscow: MGIU, 2007. pp.33-34.

[5] Benitez-Silva H., 2000, Micro Determinants of Labor Force Status Among Older Americans. Mimeo, 45 p.

[6] Becker G.S. Human Capital: A Theoretical and Empirical Analysis with Special Reference to Education. Chicago, London: The University of Chicago Press, 1992, 215 p.

[7] Barr, N., 1999, A Public-Private Partnership in Pensions: Getting the Balance Right // Agulnik, Ph., Et al, Partnership in Pensions? Responses to the Pension Green Paper, CASE Paper No. 24, April, p. 30-45.

[8] Baskakov V.N. About pensions for men and women: social aspects of pension reform [O пенсиях для мужчин и женщин: социальные аспекты пенсионной реформы]. Moscow: The Moscow Philosophical Foundation, 1998. 200 p.

[9] Borisov V.A. Demography. [Демография]. M .: Publishing house NOTABENE, 2001. 272 p.

[10] Zakharov S.V., Rakhmanova G.V. Demographic context of pensions: history and modernity [Демографический контекст пенсионного обеспечения: история и современность]. Modern problems of the pension sector: comments of economists and demographers [Современные проблемы пенсионной сферы: комментарии экономистов и демографов] / Pod. Ed. Maleva TM - Moscow: Moscow. Carnegie Center, 1997. - pp. 32-59.

[11] Pension provision in different countries of the world [Пенсионное обеспечение в разных странах мира]. Electronic portal "Pension expert" [Электронный портал «Пенсионный эксперт»]. Access mode: http://pensia-expert.ru/materialy/pensionnoe-obespechenie-v-raznyxstranax-mira/.

[12] Yakushev, L.P. About the world experience and national peculiarities of the Russian pension system. [О мировом опыте и национальных особенностях российской пенсионной системы] // Pension, 1998, № 3.

[13] Barr, N., 2000, Reforming Pensions: Myths, Truths, and Policy Choices, Working Paper No. WP / 00/139, IMF, August. 57 p.

[14] Blondal, S., Scarpetta, S., 1998, The Retirement Decision in the OECD Countries, Economics Department Working Paper No. 202, ECO / WKP 15, OECD, 107 p. URL: http://www.oecd.org/eco/eco

[15] Whelpton, P.K. Population of the United States, 1925 to 1978 / RK Whelpton // The American Journal of Sociology 34. - 1928. - №2. - pp. 253-270. 